\title{
DESIGNING DATA ACQUISITION KIT SUPPORT FOR ENVIRONMENT MONITORING
}

\author{
PHAM TRAN BICH THUAN, NGUYEN THE HOANG \\ Industrial University of Ho Chi Minh City; \\ phamtranbichthuan@iuh.edu.vn,nguyenthehoang@iuh.edu.vn
}

\begin{abstract}
It is essential to continuously observe and monitor the environment, because of unpredictable change of climate and increase of air pollution. To do that, a system, which can warn abnormalities or risks of air pollution and deterioration, then create a database of environmental quality, is needed. In order to improve the ability to provide real time data and regional environmental warnings, we proposed a compact design for data acquisition and transmission through GPRS to the center. Data acquisition systems are analogue signals as inputs, those allow sensors to measure environmental parameters (temperature, humidity, and CO). These data are stored directly on the memory of the module, then they will be transferred to the storage center. After that, all the data will be analyzed at the center. In the end of the process, warnings of changing environment will be given by the system. In addition, the design has a GPS position tracking to point out exactly its location of installation. The working design will be supported by solar panels for a whole 24-hour operation. Furthermore, by changing sensors at the inputs and flexibly reinstalling the program on the module, our design is also looking forwards to the IoT (internet of thing), one of the latest tendency of application of new technology.
\end{abstract}

Keywords. Environment monitoring station, Air quality monitoring station, Data acquisition module, Microcontroller-ARM, Internet of Thing (IoT).

\section{INTRODUCTION}

At present, the environment monitoring is very necessary. The automated operation and continuous of environment monitoring station to identify spatial changing in environmental quality (through parameters). The system creates a database of environmental quality and warns abnormalities about pollution risks or degrade the environment so on. In order to improve the ability provide real time data and abnormalities on the regional environment, the development and management of the environmental monitoring system is one of the contents of environmental protection management in Vietnam as well as in all countries in the world [1].

Worldwide: The standard environmental quality system based on each country's circumstance and they put human health at the first priority; Funding for major environment monitoring activities; Human resources are well trained; With the number of automated monitoring stations is 1987 in Japan, every 200,000 people per a station at the United States [2].

In Viet Nam. From 2009 to 2013, there are seven air quality management stations were invested and installed by the Ministry of Natural Resources and Environment at six provinces: HaNoi, PhuTho, QuangNinh, ThuaThienHue, Da Nang and KhanhHoa; With a small number of stations that have not met the management requirements and do not reflect the comprehensive quality of water and air over time. And the lack of regulations on automatic self-monitoring of emissions for some industries [2,3].

From 2002, there were nine air quality management stations were invested and installed at HoChiMinh City by Denmark and Norway, However, they have not been operate since 2009. With the increase in population, it is necessary to increase the number of monitoring stations from 10-15 the automatic monitoring stations, 35-45 monitoring stations in order to be able to evaluate in time, details. And needs to reinvest 9 air-monitoring stations that have been damaged in the past [4].

The Department of Natural Resources and Environment of Hochiminh city is building the project: "Environmental Monitoring and Analysis Center ", which includes two automatic air environment monitoring stations. At the same time, the department is also developing the project: "Overall development of the network of environmental monitoring for City by 2020, and vision to 2030". It is expected that will expand 5 sites for air environment monitoring by 2016 [5]. 
However, most of the monitoring stations are based on foreign technology such as 6 stations were invested by the technology of Horiba - Japan and Grim - Germany. The air monitoring stations located in Ho Chi Minh Mausoleum and BaDinh Square were invested by DOAS technology of OPSIS - Sweden and an automatic measurement - radioactive warning RM-A1 system[3], other stations based on American, Australian and French technology [2,7,8]. These led to difficult to development and synchronous all air monitoring stations in the environment monitoring system of Vietnam. In addition, the company also just handed over equipment's and operate them and not regularly at Vietnam after the installation is completed. These led to many difficulties in adjusting genuine equipment due to geographical distance so the coordination and handling of incidents between investors, contractors and localities has not been timely. The supporting of genuine company is not high, there were many problems encountered not in the manufacturer's recommendations. As well as, most of the experience of Vietnamese's expert through the repair, troubleshooting. Therefore, they need very long time to can understand and operate the station smoothly, quickly deal with problems. Some staff are part-time, so in many cases, they are not timely treated in case of problems. Sometimes they are not active in troubleshooting and cooperate with the environment monitoring center in troubleshooting $[2,7,8]$.

With the aim of mastering the technology and through that will be troubleshooting instantaneous, as well as that can be manageable equipment and adjust and change in accordance with the environment and geography of Vietnam. We designed a data acquisition system with inputs are the analogue and digital signals, that allow to connect sensors with goal of helping measure the environmental parameters and they will be stored directly on the memory of equipment in place. In addition, with GPS position mounted and transmitted data to the storage and analysis center, this allow to bring out waring from the center and in place when changeable weather. The system also allows on-site alarms when the current measured value exceeds the safe level as the maximum allowable temperature, there will be on-site warnings and / or via SMS, so it will help relevant departments to deal with in a timely manner. Another goal of mastering the technology by through this design. We would like to support special application at Vietnam as weather, agriculture, so on. Specially that is reducing price of equipment and repair them more easer.

The rest of this paper is organized as follows. Section II presents summaries of an environment monitoring station and our proposed design. Section III illustrates experimental results, conclusion and future works.

\section{PRELIMINARIES AND WORKSHOP}

We present summaries of a few today's environmental monitoring stations and our proposed design to obtain best-case.

\subsection{Preliminaries}

Most of today's environmental monitoring stations are systems that are combined from several individual modules such as the one shown in Figure. A system of automatic and continuous measurement of air environment elements placed in a special air-conditioned shelter. The station is incorporated from modules: Composed of four main components; System analysis modules (dust module, gas module, meteorological system, auxiliary system ...) ; Data transmission system (datalogue, IOVIS software ...); Computer system and data transmission Power operation $1[8,9]$. This will lead to large system. 


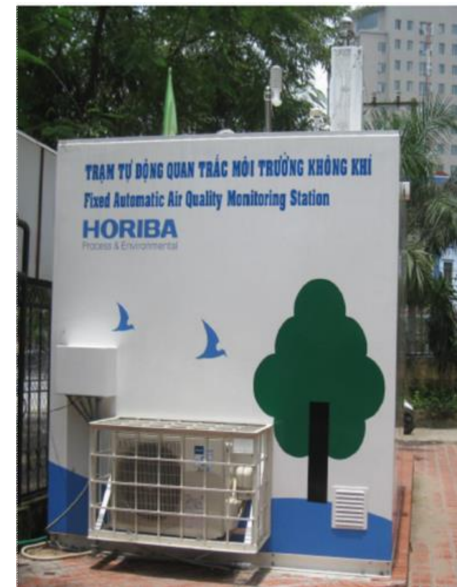

(a)

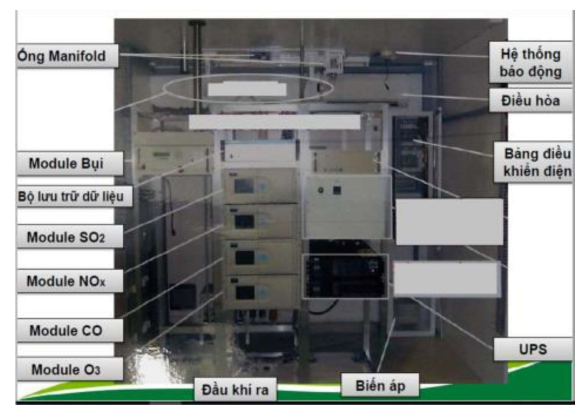

(b)

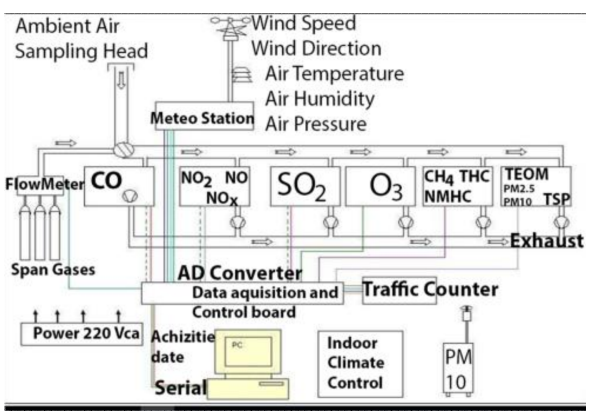

(c)

Figure 1. (a) Outside Automatic Air Quality Monitoring Station, (b) Equipment architecture inside station, (c) Block diagram of devices [8].

The transmission and data connection for the control center is shown in Figure 2: The system requires a computer to store data and, through an internet connection, transmit to a central machine. Computers, printers were installed IOVIS software to achieve configuration for the Dataloger and control modules.

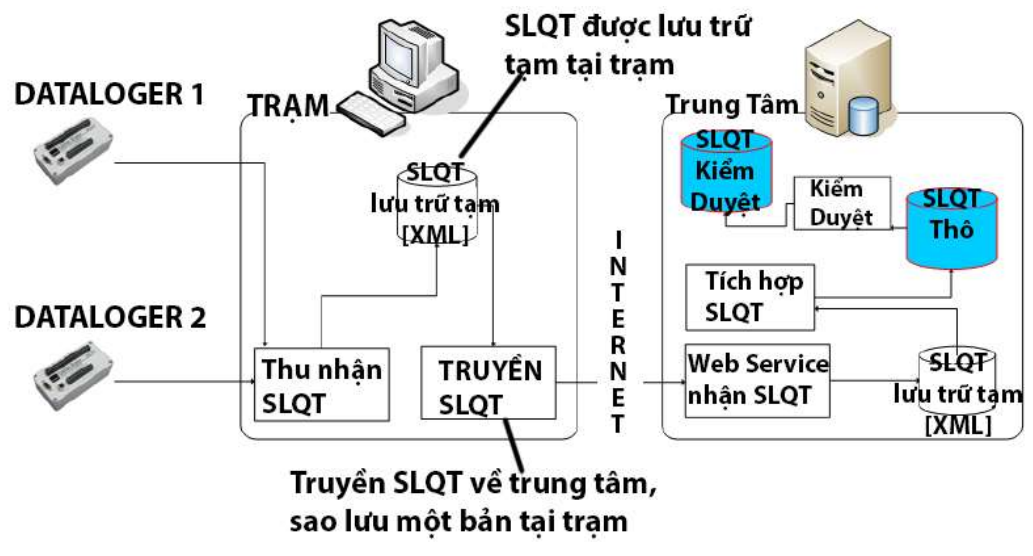

Thiết bị thu nhận và xử lý số liệu (Dataloger)

Figure 2. Model of transferring and storage data [8].

Resolution 16/2007/QD-TTg was amended and supplemented with automatic and continuous environmental monitoring network planning with increasing number and quality of stations. Strengthen the exchange of information, observation and dissemination data, disclosure of information and monitoring data in various forms (web pages, electronic sign boards, etc.), building a warning system $[8,10]$. The system is suggested as shown in Figure 3. 


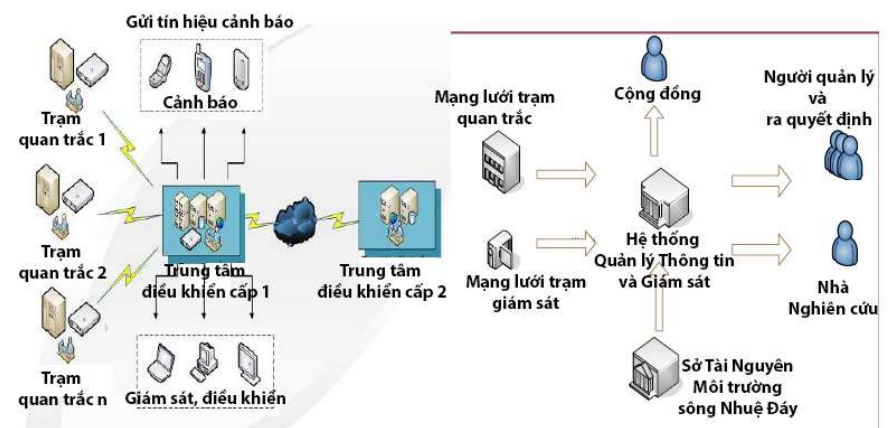

(a)

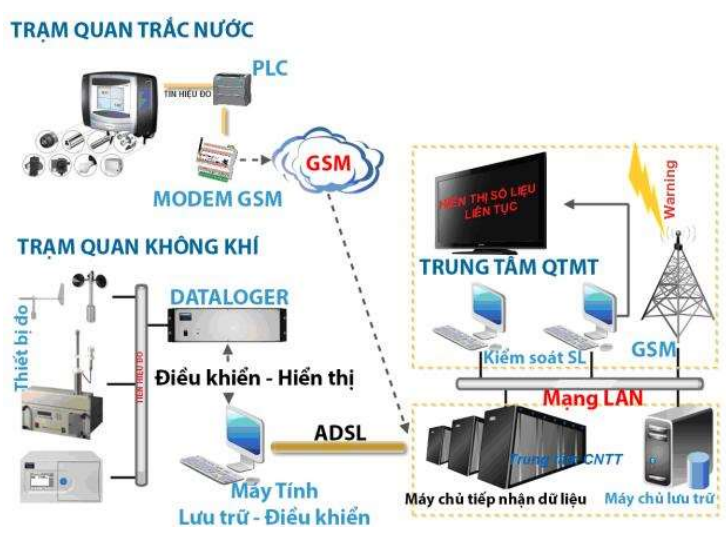

(b)

Figure 3: Model of transferring and storage data in the new orientation, (a) [8], (b) [9].

\subsection{Workshop}

Based on trend increasing number and quality of stations, we proposed designs in Figure 4 and 5 as following:

Center Processing Unit is Cortex ${ }^{\circledR}-\mathrm{M} 4$ processor. It is a high performance 32-bit processor designed for the microcontroller market. It offers significant benefits to developers, including: - Outstanding processing performance combined with fast interrupt handling - Enhanced system debug with extensive breakpoint and trace capabilities - Efficient processor core, system and memories - Ultra-low power consumption with integrated sleep modes • Platform security (datasheet of ARM) [11].

Kit installed ADC modules to connect analog sensors such as temperature, humidity and CO. Kit included ADS1220: 24-Bit, 2kSPS, 4-Ch, Low-Power, Delta-Sigma ADC with PGA and Voltage Reference. The ADS1220 is a precision, 24-bit, analog-to-digital converter (ADC) that offers many integrated features to reduce system cost and component count in applications measuring small sensor signals. The device features two differential or four single-ended inputs through a flexible input multiplexer (MUX), a low-noise, programmable gain amplifier (PGA), two programmable excitation current sources, a voltage reference [12].

To support for transferring data to the center as well as storage in place, the design also has a USB interface that allows the USB storages can plus to store data and $3 \mathrm{G}$ module. Through GMS-GPS modules to locate the KIT as well as the communication data to the center by telephone data transmission. With this positioning allows the center to determine the location of the device if there is a movement, also through the GPRS transmission line is wireless not afraid of problem transmission cable and being accessible online 24/24. 
In addition, to ensure operating of the equipment 24/24, Kit has a main power supply and additional resources using solar energy, so in the event of a main power failure, the solar battery allows the system to operate continuously without interruption in the event of a power failure.

We made a data structure to transfer data between computer and our design through GMS-GPS modules as following:

- Data packet format:

Table 1. Data packet format.

\begin{tabular}{|c|c|c|c|c|c|c|c|}
\hline HEADER & USERID & DEVICEID & DATETIME & $\begin{array}{l}\text { DATA } \\
\text { FRAME }\end{array}$ & STATUS & $\begin{array}{l}\text { PACKET } \\
\text { ID }\end{array}$ & FOOTER \\
\hline 4 bytes & 4 bytes & 6 bytes & 14bytes & $\mathrm{xx}$ bytes & $\mathrm{xx}$ bytes & xx bytes & yy bytes \\
\hline \multicolumn{2}{|c|}{ + Header: } & \multicolumn{2}{|c|}{4 bytes: } & fixed & & & \\
\hline \multicolumn{2}{|c|}{ + Serial ID: } & 4 bytes: & \multicolumn{2}{|c|}{$e x-0001$ (fixed) } & & & \\
\hline \multirow{2}{*}{\multicolumn{2}{|c|}{$\begin{array}{l}\text { + Device ID: } \\
\text { + Date: }\end{array}$}} & \multirow{2}{*}{6 bytes: } & \multicolumn{4}{|c|}{ ex - F15001 (can c } & \\
\hline & & & \multicolumn{3}{|c|}{ ex - 20140911 (11-9-2014) } & & \\
\hline \multicolumn{2}{|c|}{ + Time: } & $\begin{array}{l}8 \text { bytes: } \\
6 \text { bytes: }\end{array}$ & \multicolumn{5}{|c|}{ ex - 083900 ( 8 hours 39 minutes 00 seconds) } \\
\hline \multicolumn{2}{|c|}{ + Data Frame : } & $\mathrm{x}$ bytes & \multirow{2}{*}{\multicolumn{5}{|c|}{$\begin{array}{l}\text { (string) Contains sampling time and data channels } \\
\text { (string) Flexible lenoth }\end{array}$}} \\
\hline \multicolumn{2}{|c|}{ + Status: } & $\mathrm{x}$ byte : & & & & & \\
\hline \multicolumn{2}{|c|}{ + Packet ID: } & $\mathrm{x}$ byte : & \multirow{2}{*}{\multicolumn{5}{|c|}{$\begin{array}{l}\text { (string) Flexible length } \\
\text { (string) “OF0F"(fixed) }\end{array}$}} \\
\hline \multicolumn{2}{|c|}{ + Footer, CRC: } & 4 bytes & & & & & \\
\hline
\end{tabular}
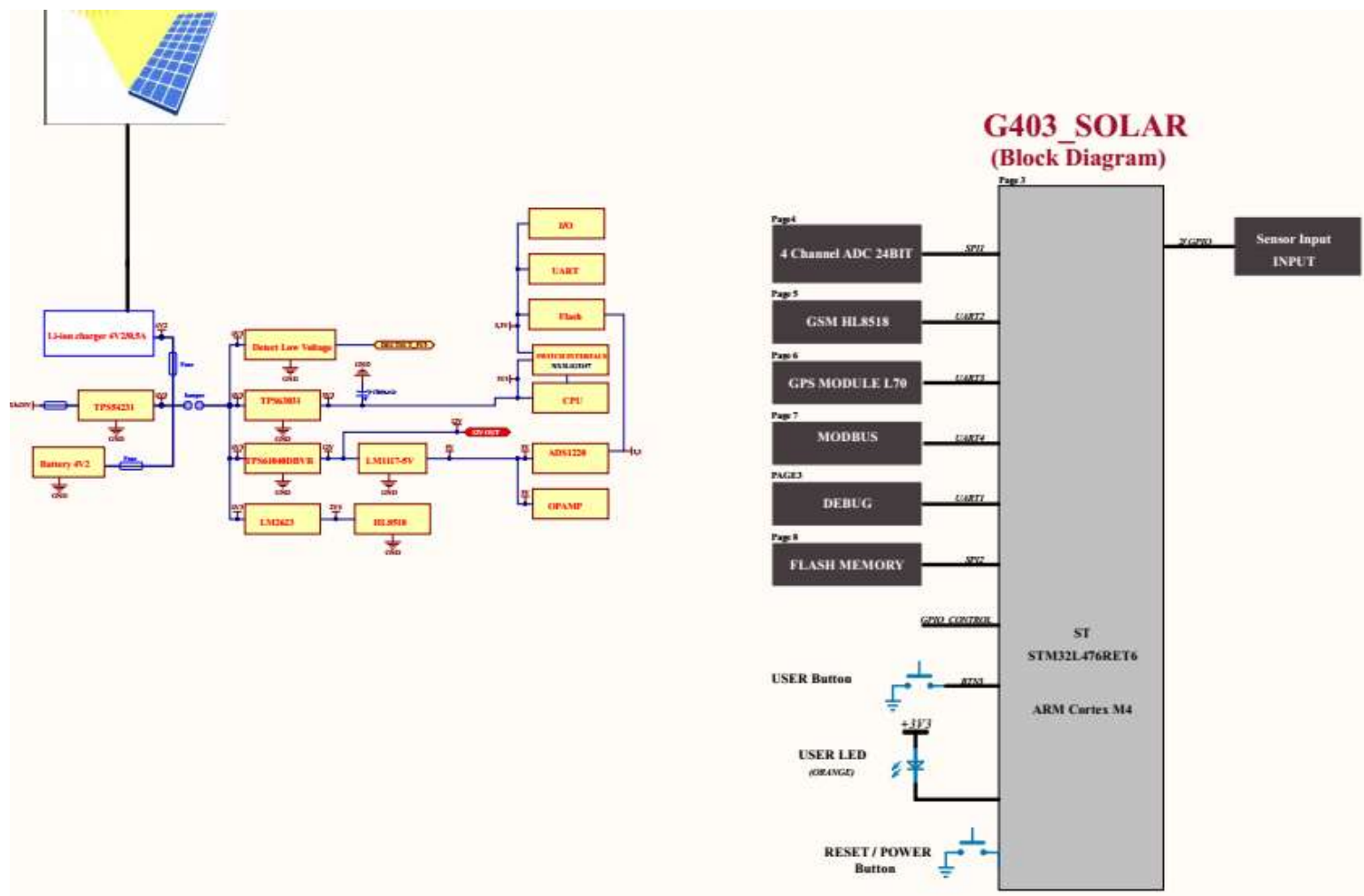

Figure 4. Block diagram 1 of our proposed designs. 


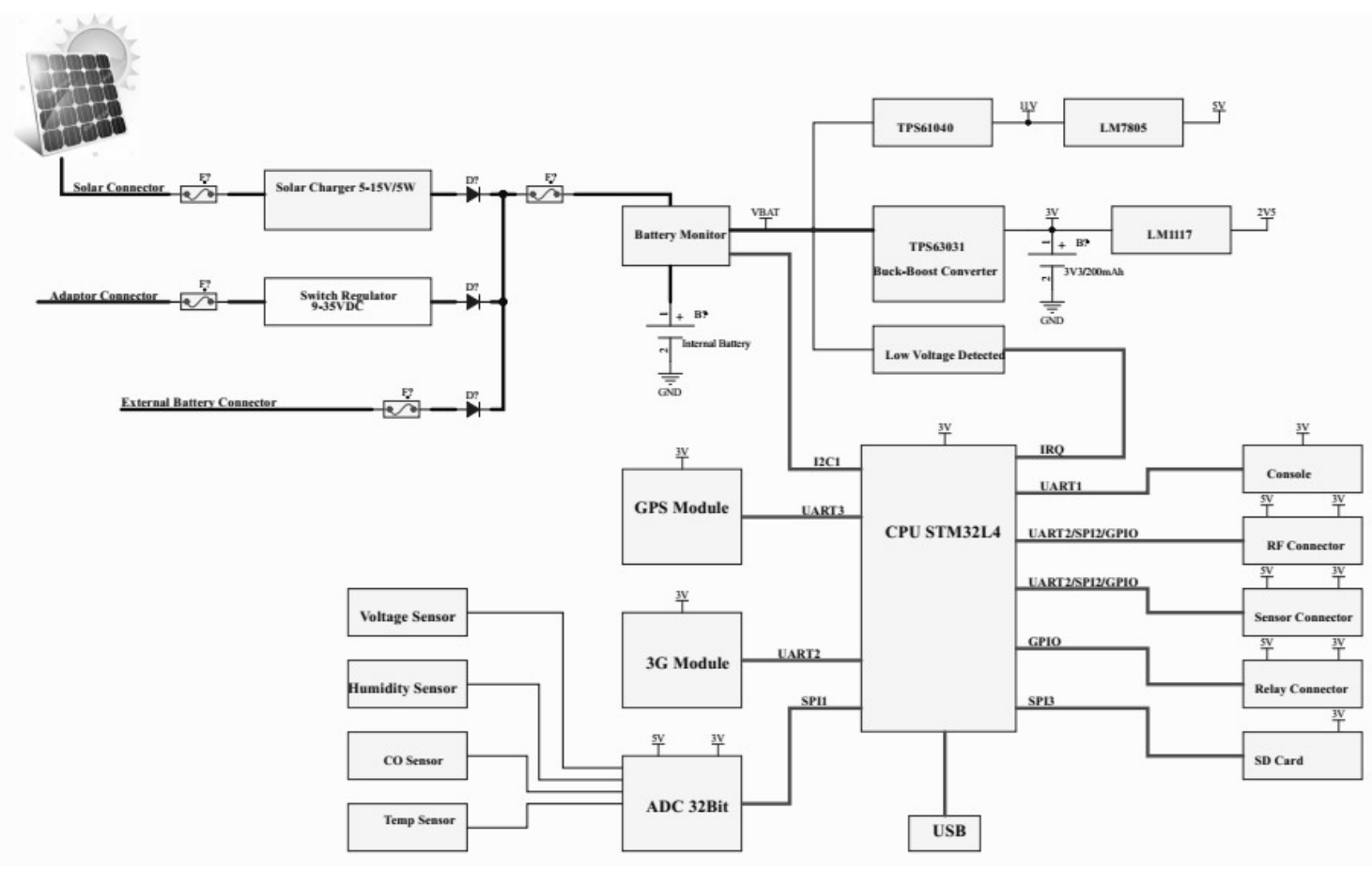

Figure 5. Block diagram 2 of our proposed designs.

- Data Response from server:

Table 2. Data response packet format.

\begin{tabular}{|c|c|c|c|c|c|c|}
\hline $\begin{array}{c}\text { HEADE } \\
\text { R }\end{array}$ & COMMAND & PARAMETER & COMMAND & PARAMETER & COMMAND_ & PARAMETER _ \\
\hline "CMD:" & 4 bytes & xx Byte & 4 bytes & xx Byte & 4 bytes & xx Byte \\
\hline
\end{tabular}

Server can send many commands at the same time by using ',' and maximum nine commands.

Table 3. Response information.

\begin{tabular}{|l|l|}
\hline BASIC COMMAND & DESCRIPTION \\
\hline "OKACK" & Confirm the server received the packet \\
\hline "NAK" & Confirm Error \\
\hline "SAMPXxxx" & Configure send time (xxxx minute) \\
\hline "DATEddmmyyyyhhmmss" & Synchronize time \\
\hline "BOOT" & Reset system \\
\hline
\end{tabular}

\section{RESULTS AND CONCLUSIONS}

The environment monitoring Kit are designed by using Altium designer software for PCB and using Keil C language with the platform of ST semiconductor. Hardware structure is presented in figure 6 for block diagram 1 in Figure 4.

The designed environment monitoring Kit has parameters as following:

- Low Current Consumption: As Low as $120 \mu \mathrm{A}$ (type) in Duty-Cycle Mode

- Wide Supply Range: $2.3 \mathrm{~V}$ to $5.5 \mathrm{~V}$

- Programmable Gain: $1 \mathrm{~V} / \mathrm{V}$ to $128 \mathrm{~V} / \mathrm{V}$

- Programmable Data Rates: Up to 2kSPS

- Up to 20-Bits Effective Resolution

- Simultaneous 50-Hz and 60-Hz Rejection at 20 SPS with Single-Cycle Settling Digital Filter

- Two Differential or Four Single-Ended Inputs 
- Dual Matched Programmable Current Sources: $10 \mu \mathrm{A}$ to $1.5 \mathrm{~mA}$

- Internal 2.048-V Reference: $5 \mathrm{ppm} /{ }^{\circ} \mathrm{C}$ (typ) Drift

- Internal 2\% Accurate Oscillator

- Internal Temperature Sensor: $0.5^{\circ} \mathrm{C}$ (typ) Accuracy

- SPI-Compatible Interface (Mode 1)

- Dual-band: GSM 900/1800 MHz

- 3GPP release 99

- Class 10/8 GPRS multi-slot

- Compliant to GSM phase $2 / 2+$

- HTTP / 1.1 transmission protocol

- Sampling rate up to $1 \mathrm{sec}$, transfer rate from 1 minute - 12 hours (can be set).

- GPS chipset: Channels: 66 parallel searching, 22 tracking channels, Sensitivity: $-165 \mathrm{dBm}$ (Tracking)

- Real Time Clock support

- Support temperature sensor $-30 \mathrm{C}->100 \mathrm{C}$, error tolerance $0.5 \mathrm{C}$ within range $-10->85 \mathrm{C}$. Humidity $0-95 \%$, error $2-5 \%$. CO gas detector: detection range from $10-1000 \mathrm{ppm}$.

- Operating voltage 7-15VDC, $0.5 \mathrm{~A}$.

- Power consumption of $<200 \mathrm{~mW}$

- Package: $3.5-\mathrm{mm} \times 3.5-\mathrm{mm} \times 0.9-\mathrm{mm} \mathrm{VQ}$

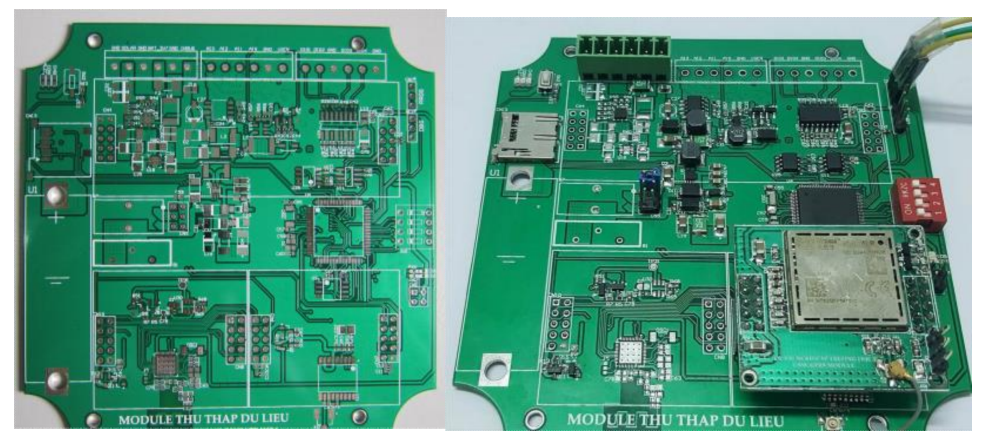

(a)

(b)

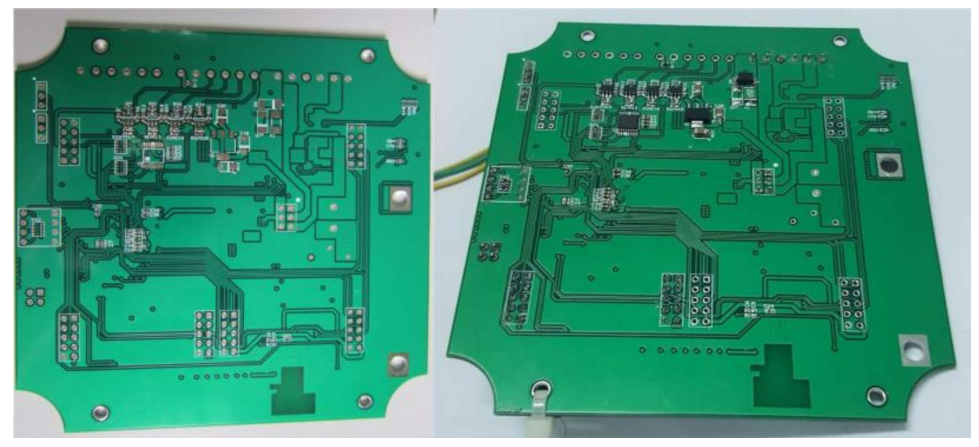

(c)

(d)

Figure 6. (a -b) before and after welding of components of layer 1.

(c -d) before and after welding of components of layer 2.

Table 4 and 5 show some data errors when the system is operated. 
Table 4. Reference temperature errors.

\begin{tabular}{|c|c|c|}
\hline Temperature value & Reference value & Error \\
\hline $26.4^{\circ} \mathrm{C}$ & $26.0^{\circ} \mathrm{C}$ & $0.4^{\circ} \mathrm{C}$ \\
\hline $28.2^{\circ} \mathrm{C}$ & $28.8^{\circ} \mathrm{C}$ & $0.6^{\circ} \mathrm{C}$ \\
\hline $30.1^{\circ} \mathrm{C}$ & $30.5^{\circ} \mathrm{C}$ & $-0.4^{\circ} \mathrm{C}$ \\
\hline $32.7^{\circ} \mathrm{C}$ & $32.5{ }^{\circ} \mathrm{C}$ & $0.2^{\circ} \mathrm{C}$ \\
\hline $33.5^{\circ} \mathrm{C}$ & $33.5^{\circ} \mathrm{C}$ & $0.0^{\circ} \mathrm{C}$ \\
\hline $34.1^{\circ} \mathrm{C}$ & $34.0^{\circ} \mathrm{C}$ & $-0.1^{\circ} \mathrm{C}$ \\
\hline $37.7{ }^{\circ} \mathrm{C}$ & $38.1^{\circ} \mathrm{C}$ & $0.4^{\circ} \mathrm{C}$ \\
\hline
\end{tabular}

Table 5. Reference humidity errors.

\begin{tabular}{|c|c|c|}
\hline Humidity value & Reference value & Error \\
\hline $98 \%$ & $99 \%$ & $1 \%$ \\
\hline $87 \%$ & $85 \%$ & $-2 \%$ \\
\hline $82 \%$ & $82 \%$ & $0 \%$ \\
\hline $78 \%$ & $77 \%$ & $-1 \%$ \\
\hline $76 \%$ & $76 \%$ & $0 \%$ \\
\hline $67 \%$ & $69 \%$ & $2 \%$ \\
\hline $56 \%$ & $54 \%$ & $2 \%$ \\
\hline
\end{tabular}

The kit has been tested for accuracy such as data acquisition from sensors and data transfer to the central computer via GPRS. The computer installed a webserver with database to store data and show results to users or individuals who interested in environmental research work. Kit's data is sent to the center for 5 minutes per packet, including temperature, humidity and $\mathrm{CO}$ at the point of collection. The system has been running and transmitting stable data on the central computer with high stability, except for occasional $3 \mathrm{G}$ network problems. This $3 \mathrm{G}$ fault is not caused by the kit that is the telecom service provider. Individuals and organizations can view the data on the website: www.emspro.tk (Please contact authors to login and view data).

By mastering the technology through the successful development of the Data Collection Kit, Kit will be able to repair when it crashes, as well as apply Kit on multiple fields. Applications that Kit can support including not only support for environmental monitoring but also support for training and teaching such as microcontroller courses, interface peripherals courses with analyze the structure, program the central controller and communicate with the webserver. In addition, changing to the system's input devices, as well as algorithms in the controller unit, Kit can assist in monitoring the temperature and $\mathrm{CO}$ at the laboratories such as mechanical machine operation rooms, chemical laboratories ... Or it can be extended to changing probes to aid in determining the parameters of running water and wastewater. Today, the one of the main interested directions that is Green Farming, which allows water to be measured, will provide automatic irrigation solutions that support smart homes or irrigated agriculture. And this is also the product that fits the trend of the future is the Internet of Thing.

\section{ACKNOWLEDGMENT}

This work is supported by "Industrial of University Ho Chi Minh City Science Foundation. Many thanks must go to our faculty and our friends who have been a source of ideas, materials and hearty support at every stage of our research. 


\section{REFERENCES}

[1] Tạ Hồng Yến - TT Quan trắc và Bảo vệ môi trường, Sở tài nguyên và môi trường Phú Thọ, "Giới thiệu về hệ thống quan trắc môi trường không khí tự động liên tục", 2013

[2] Nguyễn Thị Nguyệt Ánh, “GIỚI THIỆU HỆ THỐNG QUAN TRĂC MÔI TRUỜNG TỤ' ĐỘNG, LIÊN TỤC”, Trung tâm Quan trắc môi trường, Tổng cục Môi trường, 2011.

[3] Nguyễn Văn Thùy, Phạm Thị Vương Linh, Phạm Ngọc Hóa - Trung tâm Quan trắc môi trường, Tổng cục Môi trường, "Xây dựng, hoàn thiện hệ thống trạm Quốc gia quan trắc tự động môi trường không khí.", cổng thông tin quan trắc môi trường, tổng cục môi trường, 2014

[4] http://thietbiphantichmoitruong.com/THU-VIEN/2319138/23645/Cac-quy-dinh-ve-quan-trac-moi-truongQuan-trac-moi-truong-tu-dong-lien-tuc.html

[5] Quyết định số 355 / QĐ-UBND của Ủy ban nhân dân thành phố Hà Nội về "Quy hoạch mạng lưới quan trắc không khí cố định trênđịa bàn thành phố Hà Nội đến 2020”, 2012

[6] http://www.tienphong.vn/xa-hoi/he-thong-quan-trac-moi-truong-tu-dong-843591.tpo

[7] Trung tâm Quan trắc môi trường, "TỔNG QUAN HỆ THỐNG QUAN TRẮC VÀ PHÂN TÍCH MÔI TRƯÒ̀NG”, 2013

[8] Tổng cục môi trường, Trung tâm quan trắc môi trường, "TỔNG QUAN HOẠT ĐộNG QUẢN LÝ VẬN HÀNH CỦA CÁC TRẠM QUAN TRẮC MÔI TRƯỜNG KHÔNG KHÍ TỤ’ ĐỘNG, CỐ ĐỊNH”, 2014.

[9] Thomas Eisenmann, "Environmental Monitoring at HORIBA Europe Past, Present and Future". Available: http://www.horiba.com/uploads/media/RE06-10-048.pdf.

[10] Trung tâm quan trắc và kỹ thuật môi trường tỉnh Đồng Nai, "HộI THẢO QUAN TRĂC MÔI TRƯÒ̀ TU Tư ĐộNG, LIÊN TỤC”, 5/2012

[11] STlife.augmented, "PM0214 Programming manual”, April 2016. Available: http://www.st.com

[12] ADS1220 4-Channel, 2-kSPS, Low-Power, 24-Bit ADC with Integrated PGA and Reference (Rev. C). Available: http://www.ti.com/product/ADS1220

\section{SỤ๋ THIẾT KẾ KIT THU THẬP DŨ̉ LIỆ HỖ TRỢ CÔNG TÁC QUAN TRÁC MÔI TRUỪ̀NG}

Tóm tắt. Sự biến đổi khí hậu thất thường và sự ô nhiễm không khí ngày càng tăng thì việc quan trắc và giám sát môi trường liên tục là một việc cần thiết. Hệ thống có thể cảnh báo kịp thời các diễn biến bất thường hay các nguy cơ ô nhiễm, suy thoái và tạo ra một cơ sở dữ liệu về chất lượng môi trường. Nhằm nâng cao khả năng cung cấp dữ liệu kịp thời và đưa ra các cảnh báo nóng về môi trường khu vực một cách liên tục, chúng tôi đã đưa ra một thiết kế nhỏ gọn cho bộ thu thập dữ liệu và truyền dữ liệu về trung tâm thông qua GPRS. Hệ thốntg thu thập dữ liệu với đầu vào là các tín hiệu tương tự cho phép gắn các cảm biến giúp đo đạc các thông số môi trường (nhiệt độ, độ ẩm và $\mathrm{CO}$ ) từ đó sẽ lưu trữ ngay trên bộ nhớ được gắn tại chỗ và truyền về trung tâm lưu trữ và phân tích thông qua đó đưa ra những cảnh báo kịp thời. Thêm nữa thiết kế có định vị GPS để xác định chính xác vị trí lắp đặt và hỗ trợ thêm pin năng lượng mặt trời cho hệ thống hoạt động 24/24. Ngoài ra, thiết kế của chúng tôi cũng hướng đến phát triển các ứng dụng trong xu thế công nghệ mới ngày nay đó là IoT (Internet of Thing) với việc thay đổi đầu dò tại các đầu vào và cài lại chương trình cài đặt trên thiết kế một cách linh hoạt.

Từ khóa. Trạm quan trắc môi trường, Trạm quan trắc chất lượng không khí, Modun thu thập dữ liệu, Bộ vi điều khiển ARM, Kết nối vạn vật (IoT)

Ngày nhận bài: 02/04/2017

Ngày chấp nhận đăng: 09/08/2017 